特集一ガラス転移一

\title{
中性子散乱からみたガラス状態の ダイナミクス
}

\author{
Neutron Scattering Study of Dynamics in Glassy State;Recent Topics
}

\author{
筑紫格 金谷 利治 \\ Itaru TSUKUSHI Toshiji KANAYA
}

\begin{abstract}
We review some recent developments in glassy dynamics research using neutron scattering. We focus on the following three topics: (i) low-energy excitation, (ii) fast $\beta$ process, (iii) dynamic heterogeneity in glassy state. In the first and second topics, we show that recent research on glassy materials with various degrees of disorder provide useful information about the microscopic origin of low-energy excitation and fast $\beta$ process. In the third topic, a non-Gaussian parameter is introduced to evaluate dynamic heterogeneity of glassy materials through mean square displacement, and a correlation between the non-Gaussian parameter and fragility index is pointed out . Distribution functions of the mean square displacement are evaluated on the basis of Gaussian, log-Gaussian and bimodal distributions.

[incoherent inelastic neutron scattering, low-energy excitation, fast $\beta$ process, non-Gaussian parameter, lognormal distribution, bimodal distribution, fragility]
\end{abstract}

\section{1.はじめに}

ガラス形成物質は、古くは石器時代から現代の先端 素材にいたるまで様々な形で我々の生活にとけ込み、 身近なものとなっている。しかし、ガラス状態が熱力 学第 3 法則に反する熱力学的非平衡状態にあるという ことが認識されたのが1920-30年代のことである。そ のころから工業的な钼点からもガラス形成物質に関す る研究が基礎、応用両側面から大いになされてきた。 その当時の主な実験手段は、熱測定、粘弾性測定等の マクロな測定であった。もちろん、それらの測定は、 今日においてもその技術的進歩と共に重要な役割を果 たしている。これまでの多くの研究にもかかわらず、 現在もまだガラス状態およびガラス転移の本質が理解 されているとはいえない状況にあるのは、ガラス形成 物質が不均一性を持つため、および様々な空間・時間
スケールを持つ運動によって支配されているためであ ると思われる。裏を返して言えば、幅広いスケールで あらゆる角度から種々の測定をすることによって初め

\section{て本質を理解できる。}

近年、理論の進展、実験技術の進歩、コンピュータ ーシュミレーションの発展により、カララスを広い空 間、時間領域で理解できるようになり、ガラスの研究 に関する数々のトピックスが生まれている $[1,2]$ 。従 来からガラス状態やガラス転移の研究において盛んに 用いられてきた粘弾性測定や熱测定のようなマクロな 測定に対して、本稿で述べる中性子散乱測定は、分 子・原子レベルのミクロな空間スケールにおいて、速

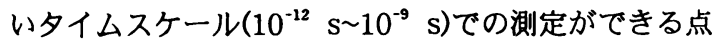
が特徵である。また锶測量が、動的散乱則、振動状態 密度、平均自乗変位というような理論との比較が直接 できる量であることも特色である。

テ611-0011 京都府宇治市五ヶ生 京都大学化学研究所

Institute for Chemical Research, Kyoto University, Uji, Kyoto-fu, 611-0011 
本稿では中性子散乱測定により明らかにされたカ ラスの研究の 3 つのトピックス、(i)ガラス状態の低 エネルギー励起の問題、(ii)速い $\beta$ 過程の問題、(iii) ガラス状態の不均一性の問題について紹介したいと 思う。

\section{2. ガラスの低エネルギー励起}

\section{1 低エネルギー励起とは？}

緩和運動が凍結される充分低い温度では、低エネ
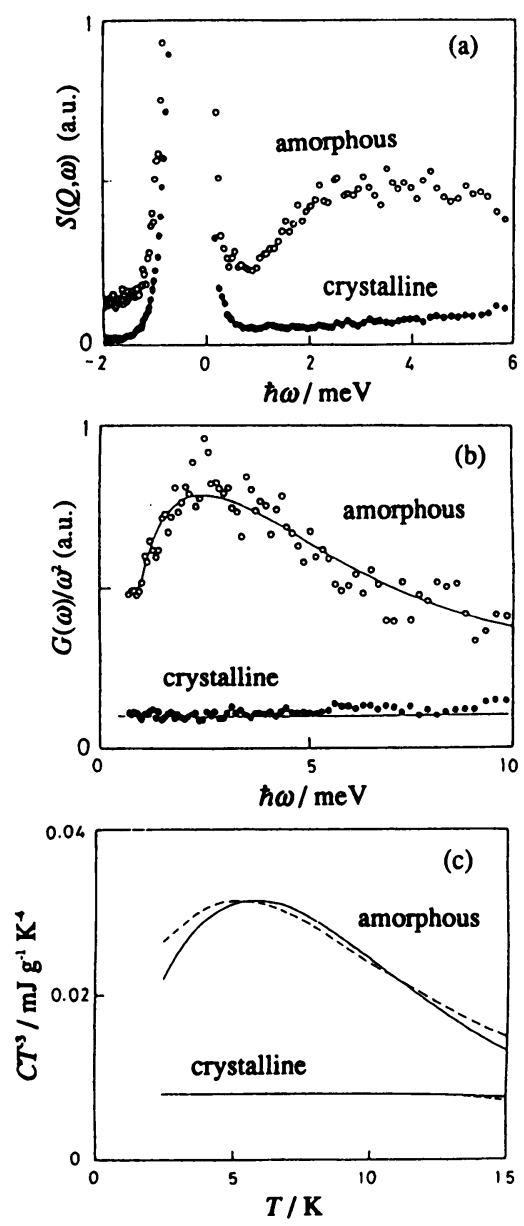

Fig. 1. (a) Dynamic scattering laws $S(Q, \omega)$ for amorphous and crystalline states of Polyethylene (PE) at $10 \mathrm{~K}$. (b) Density of vibrational states $G(\omega)$ for amorphous and crystalline states of PE. Solid lines were fitting curves. (c) Heat capacity $C(T)$ for amorphous and crystalline states of PE. Solid lines were calculated from the fitting curves to $G(\omega)$ in (b) and dashed lines are from experimental data [ref. 5].
ルギー領域もしくは低振動数領域にガラス状態と結晶 状態のダイナミクスの相違が顕著に現れる。Flg. 1(a) には、ポリエチレンのガラスと結晶の非干渉性非弾性 中性子散乱スペクトル(動的散乱則) $S(Q, \omega)$ を示してあ る[3]。ガラス状態では、 $1.5 \sim 4.0 \mathrm{meV}$ のエネルキー 範囲にブロードなピークが観測される。これがいわゆ る「低エネルギー励起」または「ポソンピーク」と呼 ばれるカララス形成物質に特有の励起である。ガラス状 態のポリエチレンでは低エネルギー励起が観測される のに対して、結晶ポリエチレンにおいては観測され ず、ガラス物質に特徽的な励起であることが分かる。 また、いくつかの例外[4]はあるが、この励起はほぼす ベてのガラス物質において観測され、ガラス物質に普 遍な現象であると言われている。Fig.1 (b) は、S(Q,w) から求めた振動状態密度 $G(\omega)$ である。10 $\mathrm{meV}$ 以下の エネルギー領域では、結晶状態の $G(\omega)$ は近似的に $\omega^{2} に$ 比例しテバイモテルで記述できることが分かる。一 方、ガラス状態の $G(\omega) / \omega^{2}$ は、 $2.5 \mathrm{meV}$ 付近にピーク をもち結晶状態に比べて過剩な状態密度を持つ。ま た、 $G(\omega)$ より求めた結晶状態とガラス状態の比熱は、 Fig.1(c)に示すように実測値 [5]によく一致し、低エネ ルギー励起が $5 \sim 20 \mathrm{~K}$ 過剩比熱の原因であること が直接示された。



Fig. 2. Molecular mass or monomer mass dependence of peak energy of low-energy excitation. $\bigcirc$ : molecular glasses (OTP;ortho-terphenyl, ETB; ethylbenzene, 3MP; 3methylpentane, 1BT; 1butene, PR; propylene), $\mathrm{O}$ amorphous polymer (PS; polystyrene, PMMA; poly(methyl methacrylate), PCP; trans-1,4-polychloroprene, PIB; polyisobutylene, PB; cis-1,4-polybutadiene, PE; polyethylene), $\square$ : monoalcohol (EOL; ethanol, MOL; methanol), $\square$ : polyalcohol (GL; glycerol). 


\section{2 低エネルギー励起の起源}

これまでの低エネルギー励起に関する研究は、そ の励起が主にガラス形成物質に普遍的であることを 示す方向で進められてきた。最近は、より詳細にカ ラス形成物質による差異に着目した研究が行われて いる。ここでは、低エネルギー励起について、種々 のガラス形成物質を系統的に調べた実験、およびカ ラス状態の無秩序度を制御し、その低エネルギー励 起への影響を調べた実験を紹介する。低エネルギ 一励起のピーク位置は、物質によっていくらか違っ ている。Fig. 2 に、種々の物質の低エネルギー励 起のピーク位置を、高分子ガラスについてはモノマ 一分子量、分子性カララスについてはその分子量の平 方根の逆数に対してプロットしたものを示す [3，69]。分子性ガラスおよびモノマー分子量が200以下 の高分子ガラスについては、ほぼ同一直線上にのつ ており、 $\omega_{\mathrm{bD}} \sim M^{1 / 2}$ の関倸がある。高分子ガラスで も、分子性ガラスと同じ線上にあることより、高分 子においてモノマー分子量の小さなものではモノマ 一間の結合の影響が見られないことがわかる。これ は、低エネルギー励起のモードが単振動的であると 仮定すると、そのバネ定数が分子間ポテンシャルで 決まっていることを示唆している。一方、モノマー 分子量200以上の高分子のガラス状態や配向性・結 合力が強い分子間水素結合をもつアルコールのガラ ス状態は、上記の関係からは外れ、分子間の結合の 強さがポソンピークの性質に大きく影響することが 分かる。

ガラス転移温度近傍での長時間アニーリングは、 ガラス状態のひずみを解消する。つまり、同じガラ ス状態にありながら乱れの程度が変化する。この乱 れの程度の低エネルギー励起への影響を調べた実験 が最近行われた。蒸着により作成されたプロピレン ガラス、および典型的なガラス形成高分子であるポ リメチルメタクリレート(PMMA)のアニーリングに よるボソンピークの変化の様子で、それぞれFig. 3 (a)と(b)に示してある[6]。いずれの場合も、ガラス 転移近傍でアニールすることにより低エネルギー励 起のピーク強度が減少しており、乱れの減少が低工 ネルギー励起強度に関係していることを示してい る。

Fig. 4 は、Ramosらによるエタノールガラスの中 性子散乱スペクトルである[7]。エタノールは適当な 熱処理を行うことにより、配向・重心ともに無秩序 な状態で凍結している構造カララスと、重心位置は規
則正しく配列(秩序化)しているが配向が乱れたまま凍 結している配向ガラス、および両方とも秩序化してい る結晶の 3 つの状態をとることができる。Fig. 4 に示 すように、結晶では低エネルギー励起が観測されない
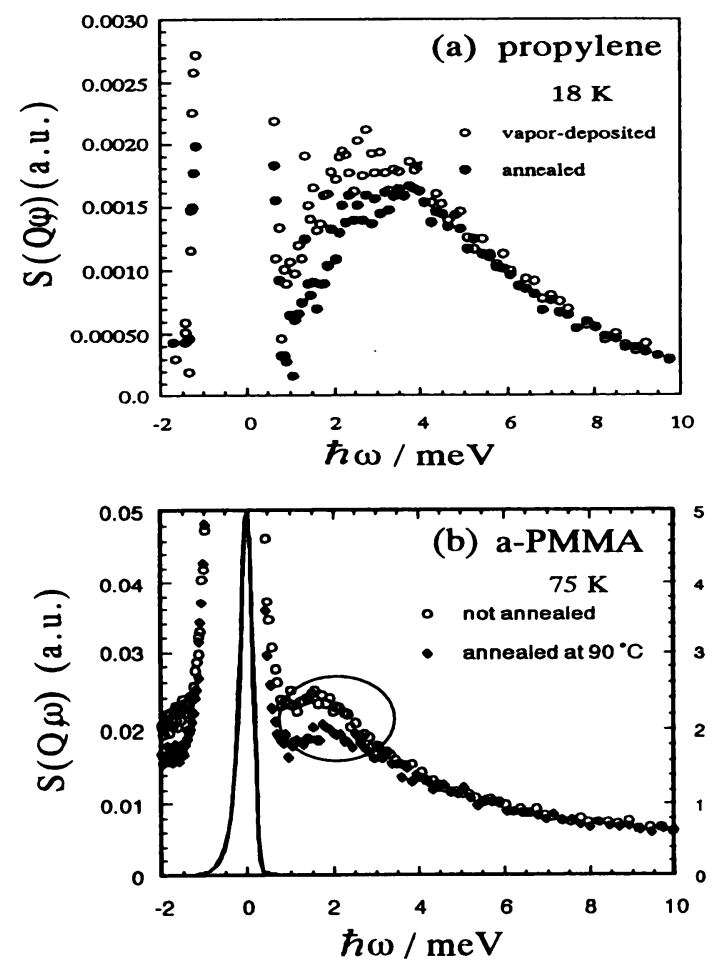

Fig. 3. Annealing effects on the low-energy excitation of (a) propylene, (b) poly(methyl methacrylate).

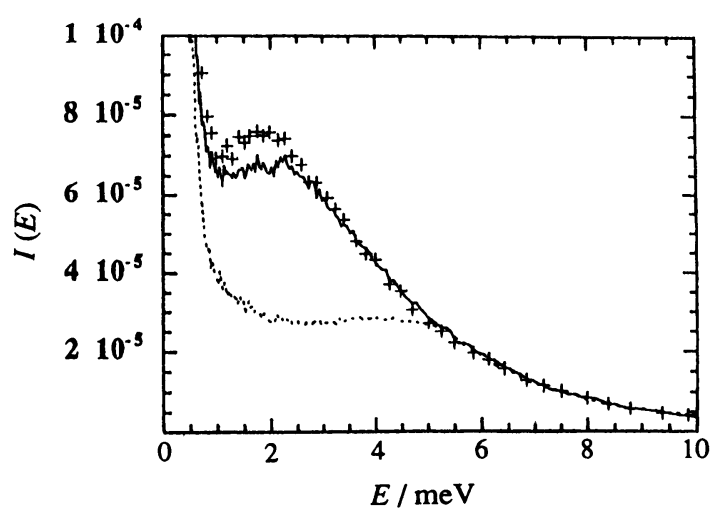

Fig. 4. A comparison of TOF spectra for deuterated ethanol for the stable crystal (dots), orientational glass (solid), and strucural glass (crosses).

のに対し、配向ガラスの方は、構造ガラスとほぼ同程 度の強度の低エネルギ一励起が観測された。これは、 
重心の秩序化は低エネルギー励起に大きく影響して いない(配向の乱れが大きく関与している)ことを示 している。

\section{3. ガラス転移近傍のダイナミクス（主に速い $\beta$ 過程 を中心として)}

\section{1 ガラス形成物質に特微的な綏和}

前節の充分低温でのガラス状態のダイナミクスを 特徵づけるのは、振動運動であった。それに対し て、ガラス転移近傍では主に緩和過程によりそのダ イナミクスが特徵づけられる。ガラス転移近傍で一 般に観測される緩和過程としては、 $\alpha$ 過程、 Johari-Goldstein過程、速い $\beta$ 過程がある。これら の過程の緩和時間の温度依存性を、ポリブタジエン を例にとってFig. 5 に示す[10-12]。 $\alpha$ 過程は、以 前から誘電緩和測定や力学緩和测定などで観測され ている緩和で、3つの緩和の中でいちばん長時間側 にあり直接カラス転移を支配すると考えられてい る。その相関関数は、一般に式(1)で示すような KWW式(伸張指数関数)で表されるのが特徽である。

$\phi(t)=\phi_{0} \exp \left[-(t / \tau)^{\beta}\right]$

相関関数が、式(1)で表せるということは、観測され た相関関数が単純な指数関数の和であるとすると、 紱和時間に分布があることを意味し、 $\beta$ が小さいほ ど紘和時間の分布がより広いことを示す。この様な 緩和時間の分布は、ガラス転移近傍では、分子が協 同的に運動することにより系が動的に不均一になる ためと考えられている。

Johari-Goldstein過程(遅い $\beta$ 過程と呼ばれること も多い)は、ガラス転移温度より上のある臨界温度 $T_{\mathrm{c}}$ から $\alpha$ 過程より分裂し、他の副緩和とは異なりあら ゆるガラス形成物質に存在する。その微視的起源に ついては、例えば $\alpha$ 過程の素過程であるとする考え [13]等があるが、一致した認識は得られていない。

速い $\beta$ 過程とは、以上二つの過程とは一見独立に ピコ秒オーダーに見られる過程である。以下に、こ の速い $\beta$ 過程の説明と最近の研究の発展について述 ベる。

\section{2 速い $\beta$ 過程とは?}

Fig. 6 にシスー1,4-ポリブタジエンの非干渉性中 性子散乱則 $S(Q, \omega)$ を、ガラス転移温度 $T_{\mathrm{g}}$ を含む温度 範囲で示す[10]。 $\omega=0$ の鋭いピークが、散乱によ りエネルギー変化を起こさない弾性散乱であり、装
置のエネルギー分解能 $\Delta \varepsilon(\sim 0.2 \mathrm{meV})$ の範囲で運動 していない分子からの寄与に対応する。分子運動によ りエネルギー変化を起こした準弾性および非弾性散乱 は、弾性散乱の裾に観測される。Fig. 6 に見られるよ うに、低い温度では、2 3 meVにブロードなピーク



Fig. 5. Temperature dependence of relaxation times of $\alpha$ process, Johari-Goldstein process and fast $\beta$ process in polybutadiene.



Fig. 6. Dynamic scattering laws $S(Q, \omega)$ of polybutadiene as a function of temperature. At low temperatures the inelastic scattering intensity is scaled by the Bose-Einstein population factor (dashed lines) while the excess intensity (fast $\beta$ process) appears at around glass transition temperature.

をもつ低エネルギー励起が観測される。その強度は温 度の上昇とともにボーズ因子に従って強くなる(図中波 
線)。さらに温度を上げて、 $T_{\mathrm{g}}$ 近傍になるとボーズ因 子の予想を超える過剩な準弾性散乱が現れ、何らか の緩和的な運動が新たに出現したことを示してい る。これが、速い $\beta$ 過程である。速い $\beta$ 過程の出現 にともない弾性散乱強度の過剩な減少や平均自乗変 位の過剩な増大も同時に観測される。

\section{3 速い $\beta$ 過程の砤視的起源}

現時点で速い $\beta$ 過程の解釈としては、ポテンシャ ルエネルギー障壁の低い二つ以上の局所的なポテン シャル間の緩和過程か、あるいはポテンシャル内で の減衰振動が考えられているが、まだ最終的な結論 は得られていない。以下では速い $\beta$ 過程の微視的起 源を明らかにしようとした最近の研究を紹介した い。
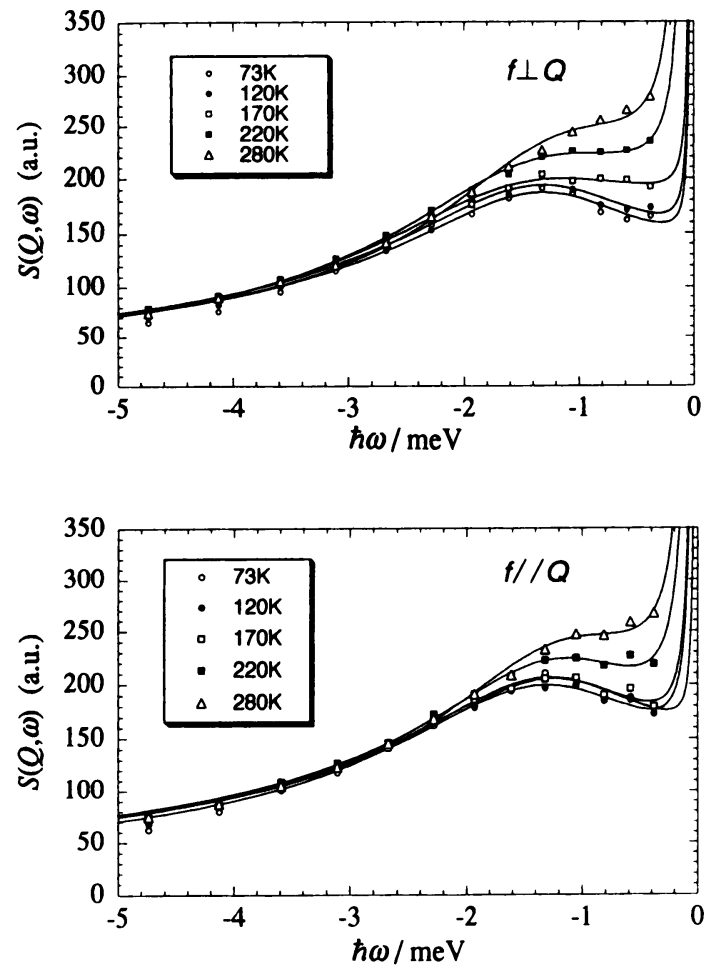

Fig. 7. Bose-scaled dynamic scattering law $S(Q, \omega)$ of amorphous PET fiber at various temperatures. (a) the perpendicular $(f \perp Q)$ geometry, (b) the parallel $(f / Q)$ geometry. The reference temperature is $73 \mathrm{~K}$.

ポリエチレンテレフタレート(PET)は、側鎖を持 たない直鎖状の高分子で、ある条件で溶融紡糸する ことによりガラス状態でありながら織維軸方向に配 向した試料を作成することができる。一軸配向した アモルファスポリエチレンテレフタレート(配向
PET)織維について、散乱ベクトルQが䋞維軸れに平行な 方向(配向方向, $f / / Q)$ と䋐維軸に垂直な方向 $(f \perp Q)$ につ いて $S(\boldsymbol{Q}, \omega)$ を測定した。Fig. 7 にボーズ因子でスケー リングした $S(\boldsymbol{Q}, \omega)$ を示してある[14]。織維軸に垂直な 方向の方がより低い温度 $(170 \mathrm{~K})$ より速い $\beta$ 過程が出現 している。このことより、速い $\beta$ 過程の微視的起源と して分子軸に平行な方向に現れる強い結合定数を持っ たbending運動よりも、分子軸に垂直な方向に現れる 例えば分子軸回りのtorsion運動やlibration運動のよう な弱い結合定数を持つ運動が関与していると考えられ る。

さらに、最近Colmeneroらのグループは、16種類の アモルファス高分子について速い $\beta$ 過程の現れ始める 温度 $T_{f}$ を検討した。そこで $T_{f}$ が主鎖の炭素間結合 $(\mathrm{C}-\mathrm{C}$ 結合)のねじれ運動に対するポテンシャル障壁 $E_{\mathrm{a}}$ と相関 していることを指摘し、速い $\beta$ 過程の起源として高分 子のセグメント運動 $(\alpha$ 過程)の短時間領域の運動であ るとの提案をしている[15]。

また、最近Tölleらによって、オルトテルフェニル (OTP) のガラス転移点近傍での圧力依存性 (0.1 MPa〜 $250 \mathrm{MPa}$ )を中性子散乱で測定した結果が報告された [16]。そこでは、 $\alpha$ 過程に対する動的散乱則 $S(Q, \omega)$ が、ナ秒からピコ秒の短い時間領域でも粘度により スケールできること、301 Kでの等温圧力変化の測定 で、加圧と共に100 MPa付近より速い $\beta$ 過程が消失す ることが報告された。現時点では、速い $\beta$ 過程への圧 力効果については、温度効果から予想される範囲内の 影響しか示されていない。

\section{4. ガラス状態の不均一性の問題}

カラス転移近傍で見られる $\alpha$ 過程の楥和時間てもし くは粘度)温度依存性は、Fig. 8 に示すように一般に式 (2) のVogel-Fulcher(VF)式(W L F 式に等価)によっ て表される。

$\tau=\tau_{0} \exp \left[B /\left(T-T_{0}\right)\right]$

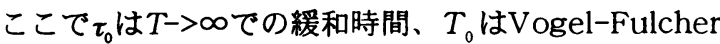
温度、Bは定数である。この式は $T>>T_{\mathrm{g}}$ では、アレニウ ス式で近似できるが、ガラス転移温度に近づくにつれ て急激に緩和時間は增大し、 $T=T_{0}$ で無限大になること を表している。つまり、ガラス転移温度に近づくにし たがって、見かけの活性化エネルギーは増加する。こ れは、充分高い温度では各分子が独立に運動できるの に対し、温度が下がるにつれて分子間相互作用のため 
いくつかの分子が協同的に運動しなければならなく なるためと考えられている。この協同的に動いてい る領域を協同運動領域 (cooperatively rearranging region）と呼ぶ。この協同運動領域の大きさが分布 して存在するため、ガラス転移温度近傍でガラス形 成物質は動的に不均一であると考えられている。 Fig. 8 から分かるように、種々のガラス形成物質の 過冷却液体領域における粘度(もしくは $\alpha$ 過程の緩和 時間)の温度依存性は、明らかに物質によって異な る。Angellはこの物質による相違をフラジリティー 指数 $m\left(=\mathrm{d}(\ln \tau) / \mathrm{d}\left(T_{\mathrm{g}} / T\right) \mid T=T_{\mathrm{g}}\right)$ を導入することによ り分類した[17]。mの大きい物質をフラジャイルな ガラス(主にOTPなどのファンテルワールスカで凝 集している分子性ガラスがこれに属する)、mの小さ な物質をストロングなガラス(主に $\mathrm{SiO}_{2}$ 等の無機ガラ スがこれに属する)と呼んでいる。

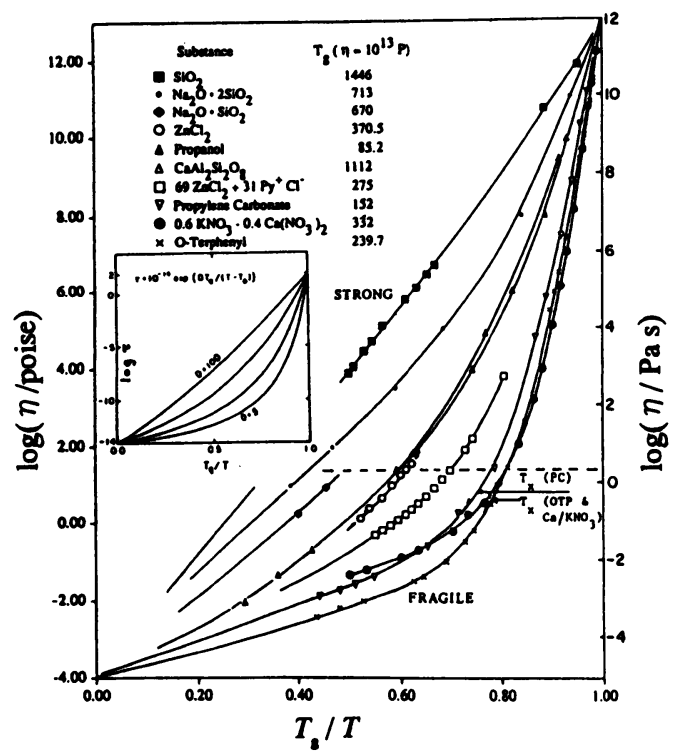

Fig. 8. Viscosity of various glass-forming materials versus $T_{g} / T$ (Angell plot).

カラス状態においても、過冷却状態での不均一性 を保持したまま凍結していると考えられる。以下で は、ガラス状態での動的不均一性の定量化と平均自 乗変位の分布について述べてみたい。

非干渉性の中性子罂性散乱強度 $I_{\mathrm{el}}$ のQ（散乱べク トル）依存性は、Gauss近似のもとでは

$I_{e l}(Q)=\exp \left(-<u^{2}>Q^{2}\right)$

で表される。ここでく $u^{2}>(=\alpha)$ は平均自乗変位で、 $u$ は構成原子の平衡位置からの変位である。しかし、
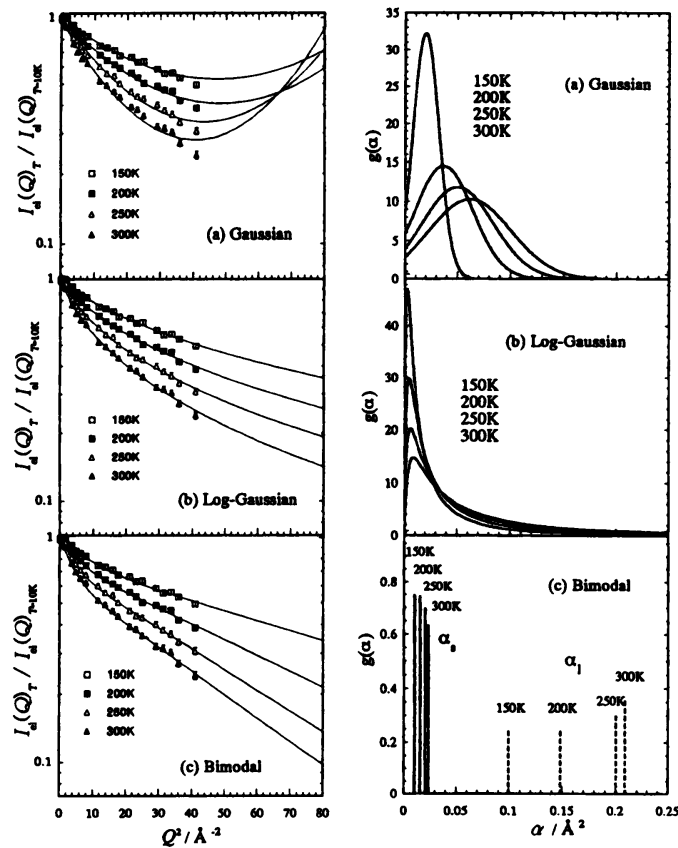

Fig. 9. $Q$ dependence of incoherent elastic scattering intensity $I_{T}(Q) / I_{10 \mathrm{r}}(Q)$ of poly(methyl methacrylate) (PMMA). In order to reduce the effects of coherent scattering, elastic scattering intensity $I_{T}(Q)$ at $T$ is divided by that at $10 \mathrm{~K}$. The solid curves are results of fit, assuming (a) Gaussian, (b) log-Gaussian and (c)bimodal distribution functions for the mean square displacement $\alpha$.

Fig. 10. Distribution functions of mean square displacement $g(\alpha)$ of PMMA evaluated from the fits shown in Fig. 9. (a) Gaussian, (b) log-Gaussian and (c)bimodal distribution functions.

ガラス状態では、Fig. 9 (a), (b), (c) に示すようにその 近似が破れている。Gauss近似が破れる理由はいろい ろと考えられるが、ガラス状態ではその不均一性のた めに近似が破れたと考えるのがもっともらしい。すな わち、平均自乗変位 $\alpha$ が不均一性のために分布をもっ ていると考えると、観測される弾性散乱強度は

$I_{e l}(Q)=\int_{0}^{\infty} g(\alpha) \exp \left(-\alpha Q^{2}\right) d \alpha$

と表される。ここで $\mathrm{g}(\alpha)$ は分布関数である。 $\mathrm{g}(\alpha)$ と してガウス分布を用いると弾性散乱強度は、Qの 4 次 の項まで展開した近似的な式として 


$$
I_{e l}(Q)=\exp \left(-\bar{\alpha} Q^{2}+\frac{A_{0} \bar{\alpha}^{2}}{2} Q^{4}\right)
$$

のように表される。ここで、 $A_{0}$ は非ガウスパラメー タと呼ばれ

$A_{0}=\left(\overline{\alpha^{2}}-\bar{\alpha}^{2}\right) / \bar{\alpha}^{2}$

となる。(6)式より明らかなように、 $A_{0}$ が大きいほど $\alpha$ の分布幅は大きく系は不均一であるとみなすこと ができる。このように、非カウスパラメータ $A_{0} に$ よってガラス状態での動的不均一性を定量化するこ とができる。非ガウスパラメータをガラス状態およ びガラス転移と関連させる研究が最近いくつか報告 されており、例えば小田垣らはとラッピング拡散モ テルによりガラス転移はガウスー非ガウス転移であ ることを示した[18]。Fig. 9 (a) の実線は、式(6)を 実測値にフィティングした結果である。4次の項ま で展開した近似式を用いたため大きなQ領域ではず れが見られるが、実測值おおむね再現される。ま た、Fig. 10 (a) にはフィティングパラメータより求 めた平均自乗変位の分布を示してある。温度の上昇 と共に $g(\alpha)$ のピーク位置が $\alpha$ の大きな方に移る。次 に、種々の高分子について調べた非ガウスパラメー タ $A_{0}$ のフラジリティーm依存性を、Fig. 11 に示す [19]。明らかに、 $A_{0}$ は、フラジリティー指数と相関 しており、ストロングなガラス形成物質ほど $A_{0}$ は大 きく、動的に不均一であることが分かる。これは、 ストロングな物質ほど強い結合性を持つために、運 動による均一化が起こりにくいためと思われる。

次に、より詳細な不均一性の評価をするために、 平均自乗変位の分布関数 $g(\alpha)$ として対数ガウス分布 と二様分布を適用した例を示す。対数ガウス分布は コンピュータシュミレーションや陽電子消滅法によ る過冷却液体やガラス状態の自由体積の分布の評価 にも使われている[20,21]。対数ガウス分布を用いる と弾性散乱強度は次式で表される。

$$
\begin{aligned}
I_{e l}(Q)= & \frac{1}{\sqrt{2 \pi \sigma_{L}^{2}}} \int_{0}^{\infty} \exp \left\{-\frac{(\ln \alpha-\ln \bar{\alpha})^{2}}{2 \sigma_{L}^{2}}\right\} \\
& \exp \left(-\alpha Q^{2}\right) d(\ln \alpha)
\end{aligned}
$$

ここで $\sigma_{L}$ は、対数ガウス分布の分散である。二様分 布において、平均自乗変位として $\alpha_{\mathrm{s}} 、 \alpha_{1}$ の2成分を 考えて $\alpha_{1}$ の割合をpとすれば、その弾性散乱強度は

$$
I_{e l}(Q)=(1-p) \exp \left(-\alpha_{s} Q^{2}\right)+p \exp \left(-\alpha_{l} Q^{2}\right)
$$

となる。

Fig. 9 (b), (c)に、(b) 対数ガウス分布、(c)二様分布を 適応してフィティングした結果を実線で示す。また、 Fig. 10 (b), (c) には、フィティング結果から求めた分 布関数が示してある。実測値とフィティング値とのず れの 2 乗は、ガウス分布に比べて、対数ガウス分布と 二様分布の方が 2 倍ほど小さく、後者の 2 分布関数の 方がよりよいフィットを与える。対数ガウス分布、二 様分布のどちらがよりよい分布関数であるのか？より 適切な分布関数とはどのようなものかなど、動的不均 一性がどのように上手く記述できるかは、例えばより 高いQ領域を測定するなどのこれからの検討課題であ る。

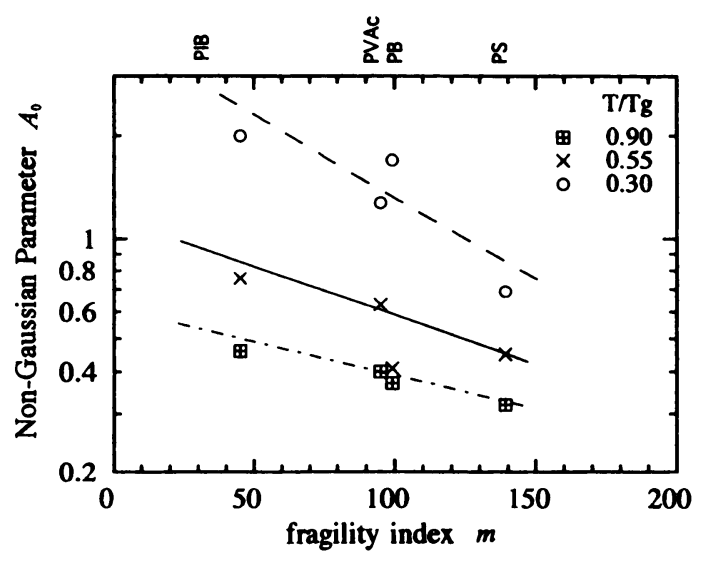

Fig. 11. The correlation between non-Gaussian parameter $A_{0}$ and fragility index $m$ at $T / T_{z}=0.3,0.55$ and 0.9 .

\section{5.さいこに}

以上、中性子散乱から見たガラス形成物質に関するダ イナミクスを紹介してきた。まず指摘したいことは、 ガラス状態のダイナミクスにおいて、不均一性が重要 な役割を果たしていることである。さらに、低エネル ギ一励起や速い $\beta$ 過程についてもガラス形成物質によ る相違に着目した実験や乱れの程度を制御する実験に より、その微視的運動モードが少しづつではあるが明 らかになってきている。しかし、現時点ではデータの 整理さえ明らかではないところもあり、議論も定性的 な段階で留まっている。理論、実験、コンピューター シュミレーション等の更なる発展と飛躍が期待され る。 


\section{参考文献}

[1] Proceedings of Yukawa International Seminar 1996 (YKIS '96), ed. by T. Odagaki, Y. Hiwatari, J. Matsui, Kyoto, Prog. Theor. Phys. Suppl., 126 (1997).

[2] Proceedings of the Third International Discussion Meeting on Relaxations in complex systems, ed. by K.L. Ngai, E. Riande, M.D. Ingram, Vigo, Spain, J. NonCryst. Solids, 235/237 (1998).

[3] T. Kanaya, K. Kaji, S. Ikeda, K. Inoue: Chem. Phys. Lett., 150, 334-338 (1988), "Low-energy excitations in polyethylene: comparison between amorphous and crystalline phases".

[4] R. Mukhopadhyay, A. Alegria, J. Colmenero, B. Frick, Macromolecules, 31, 3985-3993 (1998), "Methyl group dynamics in poly(vinyl acetate): a neutron scattering study".

[5] J. E. Tucker, W. Reese: J. Chem. Phys., 46, 13881397 (1967), "Heat capacity of polyethylene from 2.5 to $30 \mathrm{K"}$.

[6] O. Yamamuro, I. Tsukushi, T. Matsuo, K. Takeda, T. Kanaya, K. Kaji: J. Chem. Phys., 106, 2997-3002 (1997), "Inelastic neutron scattering study of low-energy excitations in vapor-deposited glassy propylene".

[7] M. A. Ramos, S. Vieira, F. J. Bermejo, J. Dawidowski, H. E. Fischer, H. Schober, M. A. Gonzalez, C. K. Loong, D. L. Price: Phys. Rev. Lett. 78, 82-85 (1997), "Quantitative assessment of the effects of orientational and positional disorder on glassy dynamics".

[8] F. J. Bermejo, J. Alonso, A. Criado, F. J. Mompeàn, J. L. Martìnez, M. Garcia-Hernàndez, A. Chahid: Phys. Rev. B 46, 6173-6186 (1992), "Low-frequency excitations in a molecular glass: Single-particle dynamics".

[9] F. J. Bermejo, A. Criado, J. L. Martìnez: Phys. Lett. A 195, 236-244 (1994), "On the microscopic origin of the "boson" peak in glassy materials".
[10] T. Kanaya, T. Kawaguchi, K. Kaji: J. Chem. Phys., 98, 8262-8270 (1993), "Low-energy excitation and fast motion near $T_{z}$ in amorphous cis-1,4-polybutadiene".

[11] D. Richter, R. Zorn, B. Frick, B. Farago, L. J. Fetters: Phys. Rev. Lett., 68, 71-74 (1992), "Decoupling of time scales of motion in polybutadiene close to the glass transition".

[12] E. Rössler, A. P. Sokolov, P. Eiermann, U. Warschewske: Physica, A201, 237-256 (1993), "Dynamical phase transition in simple supercooled liquids and polymers - an NMR approach".

[13] M. Oguni: J. Non-Cryst: Solids, 210, 171-177 (1997), "'Intra-cluster rearrangement' model for the $\alpha$-process in supercooled liquids, as opposed to 'cooperative rearrangement of whole molecules within a cluster'".

[14] T. Kanaya, R. Zorn, I. Tsukushi, M. Murakami, K. Kaji, D. Richter: J. Chem. Phys., 109, 10456-10463 (1998), "Orientational effects on low-energy modes in amorphous poly(ethylene terephthalate) fiber".

[15] J. Colmenero, A. Arbe: Phys. Rev. B 57, 13508-13513 (1998), "Carbon-carbon torsional barriers driving the fast dynamics in glass-forming polymers".

[16] A. Tölle, H. Schober, J. Wuttke, O. G. Randl, F. Fujara: Phys. Rev. Lett., 80, 2374-2377 (1998), "Fast relaxation in a fragile liquid under pressure".

[17] C. A. Angell : J. Phys. Chem. Solids, 49, 863-871 (1988), "Perspective on the glass transition".

[18] T. Odagaki, Y. Hiwatari: Phys. Rev. A43, 1103-1106 (1991), "Gaussian-to-non-Gaussian transition in supercooled fluids".

[19] T. Kanaya, I. Tsukushi, K. Kaji: Prog. Theor. Phys. Suppl., 126, 133-140 (1997), "Non-Gaussian parpameter and heterogeneity of amorphous polymers".

[20] Y. Hiwatari: J. Chem. Phys., 76, 5502-5507 (1982), "Free volumes and liquidlike clusters in soft-core dense liquids and glasses".

[21] V. Novikov, E. Rössler, V. Malinovsky: Prog. Theor. Phys. Suppl., 126, 387-391 (1997), "Fragility as a measure of dynamic inhomogeneity of glass formers".

[1999年2月 12 日受理 $]$ 